\title{
Securitization of the Migration Crisis and Islamophobic Rhetoric: The 2016 Slovak Parliamentary Elections as a Case Study
}

\author{
Lubomír Zvada \\ Palacký University
}

\begin{abstract}
This paper focuses on the migration crisis from the perspective of Slovakia while examining the impact of the crisis on the last parliamentary elections in 2016. The migration/refugee crisis that started in 2015 played a significant role during the pre-electoral discourse and political campaigns. This paper has two main goals. The primarily goal is to apply the theory of securitization as proposed by the Copenhagen Peace Research Institute on the case study of Slovakia, and the secondary goal is to analyze the 2016 Slovak general elections. In here, I describe the securitization processes, actors, and other components of the case. Subsequently, I focus on a key element of this theory that is linked to the speech act. I evaluate Islamophobia manifestations in speech act and political manifesto of Slovak political parties. My source base includes the rhetoric of nationalist political parties such as Direction-SD (Smer-SD), Slovak National Party (Slovenská národná strana), We Are Family-Boris Kollár (Sme RodinaBoris Kollár), and Kotleba-People' Party Our Slovakia (Kotleba-Ludová strana Naše Slovensko), all of which often apply anti-Muslim and anti-Islam rhetoric.
\end{abstract}

\section{Keywords}

theory of securitization; securitization of Islamophobia; securitization of migration crisis; Slovak Republic; 2016 parliamentary elections; anti-Muslim; antiIslam; speech act

\section{Introduction}

The last parliamentary elections have brought some surprising results, with scholars characterizing them as causing "a political earthquake" in the Slovak parliamentary system (Rybáŕ, Spáč 2016). Ol'ga Gyarfášová and Martin Slosiarik argued that constitutional changes caused the volatile and unstable voters' behavior (Gyarfášová, Slosiarik 2016). In her study, Aneta Világi analyzed political behavior of young voters who strongly supported populist and extreme right parties (Világi 2016). As I see it, the 2016 Slovak general elections were important in three respects.

\footnotetext{
* Lubomír Zvada, Department of Politics and European Studies, Faculty of Arts, Palacký University, Kř́žkovského 12, 77180 Olomouc, Czech Republic; lubomir.zvada01@upol.cz; ORCID: 0000-00030869-5014. The author would like to thanks to Martin Petlach and Zbyněk Vallo for their remarks and insightful comments on the manuscript. Thanks are due also to the two anonymous reviewers.
} 
First, Direction-Social Democracy (Smer-SD) led by Robert Fico had lost the parliamentary majority and Slovakia returned to a typical coalition government. ${ }^{1}$ Second, one of the traditional political parties, ChristianDemocratic Movement (Krestansko-demokratické hnutie), did not pass the five percent threshold and remained outside of the parliament. On the other hand, the populist political party We Are Family-Boris Kollar (Sme Rodina-Boris Kollár) led by a controversial billionaire, Boris Kollár, and the extreme rightwing party Kotleba-People's Party Our Slovakia (Kotleba-Ludová strana naše Slovensko) entered the parliament. Third and most important for this paper is the fact that for the first time in the history of Slovak general elections, issues of foreign policies rather than domestic policy agenda (e.g. health care system, taxes, social issues, transport network, etc.) formed the main ethos of the election campaign.

Table 1: Results of the parliamentary election of Slovak Republic 2016

\begin{tabular}{|c|c|c|c|c|c|}
\hline Party $^{2}$ & Votes & Votes (\%) & $\begin{array}{l}\text { Change } \\
2012\end{array}$ & Seats & $\begin{array}{l}\text { Change } \\
2012\end{array}$ \\
\hline Direction-SD & 737,481 & 28.28 & -16.1 & 49 & -34 \\
\hline Freedom-Solidarity & 315,558 & 12.1 & 6.2 & 21 & 10 \\
\hline Ordinary People & 287,611 & 11.03 & 2.5 & 19 & 3 \\
\hline Slovak National Party & 225,386 & 8.64 & 4.1 & 15 & 15 \\
\hline Kotleba-Our Slovakia & 209,779 & 8.04 & 6.5 & 14 & 14 \\
\hline $\begin{array}{l}\text { We Are Family- } \\
\text { Boris Kollár }\end{array}$ & 172,861 & 6.63 & 6.6 & 11 & 11 \\
\hline The Bridge & 169,593 & 6.5 & -0.4 & 11 & -2 \\
\hline \# Network & 146,205 & 5.61 & 5.6 & 10 & 10 \\
\hline Christian Democrats & 128,908 & 4.94 & -3.9 & 0 & -16 \\
\hline Hungarian Community & 105,495 & 4.05 & -0.2 & 0 & 0 \\
\hline Others & 108,874 & 4.2 & -4.6 & 0 & 0 \\
\hline Total & $2,648,184$ & 100 & & 150 & \\
\hline
\end{tabular}

Source: Slovak Statistical Office (2016)

1 Direction-SD created a new coalition with the Slovak National Party, Bridge-Híd, and \#Network. They gained 85 seats in the Slovak Parliament.

2 Political parties marked "Bold" created a coalition government led by PM Robert Fico. Nowadays, in April-May 2018 where paper is progress, Slovakia faces the biggest political crisis after the murder of investigative journalist Ján Kuciak and his fiancé. PM R. Fico, Ministry of Interior Robert Kaliňák, and President of Slovak Police Forces Tibor Gašpar resigned, and coalition government was rebuilt. Peter Pellegrini became new PM, Denisa Saková new minister of interior and General Milan Lučanský new President of police forces. 
The migration/refugee crisis became part of the public and policy discourse, and this security pseudo-threat was the main topic during the pre-election and election campaigns. Viera Žúborová and Ingrid Borárosová claimed that the migration crisis entered the Slovak print media discourse in May 2015, i.e. less than one year before the general election. Since then, an average representation of migration crisis was in the selected print media environment ${ }^{3}$ at a $50 \%$ high level, the lowest at the beginning of May 2015, and two 70\% tops in September 2015 and January 2016 (Žúborová, Borárosová 2017, 7). Looking at scholarly works available in Slovak, there has been little written on migration except of Jarmila Androvičovás paper. Androvičová analyzed the migration discourse between 2004 and 2014 (before the EU migration crisis in 2015). She claims that "for a long time, migration has not been one of the topics that would lead to intense any debate in Slovakia, unlike some other countries of the European Union. This fact is certainly related to the incomparably lower number of migrants and migrant backgrounds" (Androvičová 2015, 319). The situation changed in 2015 with a huge number of migrants coming to the EU from the MENA region. ${ }^{5}$

Migration has become an important topic in political discourse since the second half of 2015 despite the fact that according to the International Organization of Migration (IOM), the overall number of foreigners make up only $1.9 \%$ of the Slovak population in 2017. In comparison with the last year, it is slowly, yet continuously, growing with approximately a $12 \%$ increase (IOM 2018). In addition, more than $40 \%$ of all legal migrants ${ }^{6}$ come from the neighboring countries, ${ }^{7}$ following ca. 30\% migrants from South-Eastern European countries, ${ }^{8}$ and there is also a small Asian migrant community. In accordance with the newest data on migration as delivered by Eurostat, Slovakia has the lowest number (1.4) of migrants per 1,000 inhabitants (Eurostat 2018). To illustrate my point, the following two graphs show the development of applications for asylum numbers (Graph 1) and approved applications (Graph 2).

\footnotetext{
3 Žúborová and Borárosová analyzed two newspapers in Slovakia, SME (liberal, right-wing oriented) and Pravda (center-left oriented). They analyzed 420 messages during May 2015-March 2016.

4 In September 2017, thanks to the Hungarian Keleti station; in January 2016, according to the case of sexual harassment in Germany.

5 Middle East and North Africa region.

6 IOM Slovakia. "Migration in Slovakia." 2018. International Organization of Migration Slovakia. February 16, 2018. https://www.iom.sk/en/migration/migration-in-slovakia.html

7 Czech, Austrian, Ukrainian, Polish, and Hungarian citizens.

8 Romania, Bulgaria, Serbia, Russia.

9 Vietnam, Thailand, China, South Korea. 
Graph 1: Application of asylum seekers

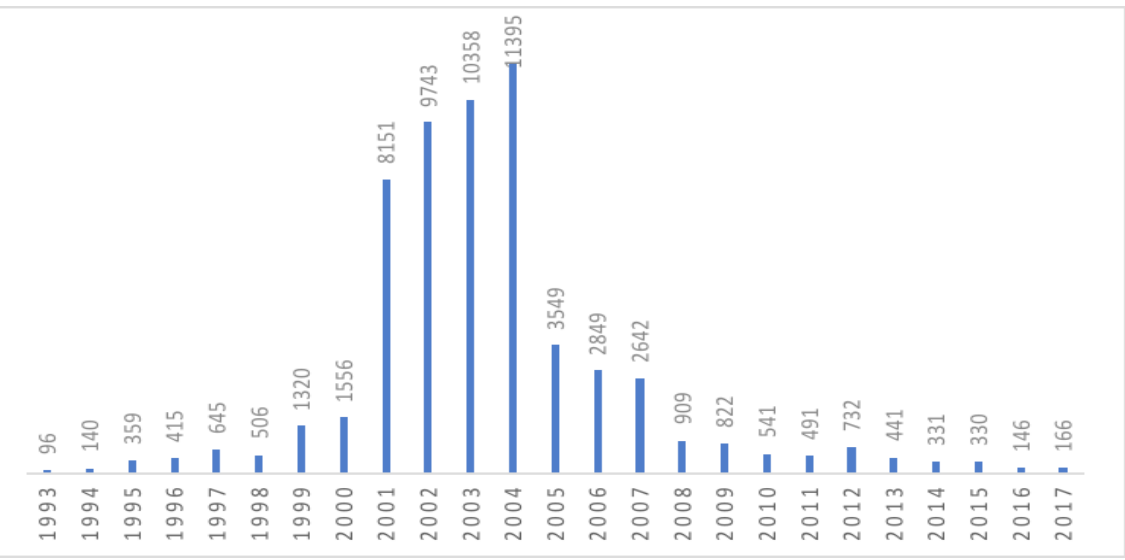

Source: Authors graph based on statistics by Ministry of Interior of Slovak Republic

Graph 2: Numbers of received asylum application

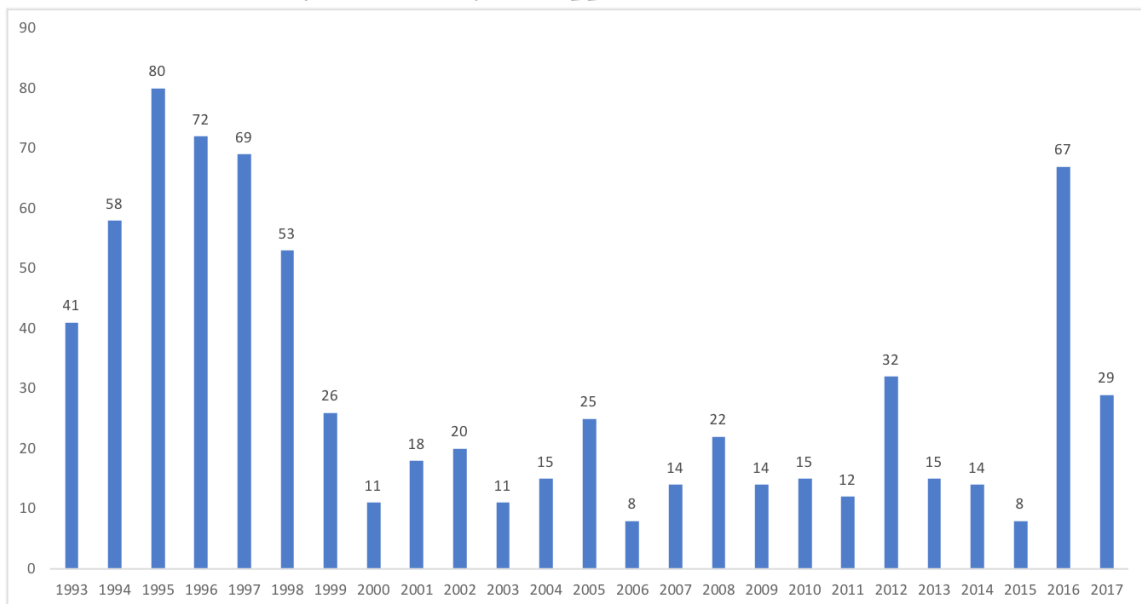

Source: Authors graph based on statistics by Ministry of Interior of Slovak Republic

The last point mentioned above stresses the migration crisis as a part of the public and policy discourse, which is analyzed here. First, I present the research design of my paper (research methods and research question; sources of data) and after that I turn to the basic theoretical framework of this paper: theory of securitization. Finally, I reflect the key point of this theory - speech act. I will not reflect all speech acts in political or societal discourse but focus on those that manifested anti-Muslim rhetoric. Lastly, in the analytical 
part of my paper, I will introduce my findings about the characteristics of securitization of Islamophobia during the migration crisis, rate of use of antiMuslim rhetoric in speech acts and how the political parties incorporated this question into their political agenda.

\section{Methodology, Data and Research Question}

In a wider context of this paper, I try to answer many questions that echoed in the pre-election or election discourse and can be used as a research question. How is it possible that the migration crisis took a central position in the political and societal discourse in the pre-election period and election campaign? How is it possible that Slovaks felt threatened despite the fact that the country ranks 22nd in the Global Peace Index? Why did Muslims and Islam become the main topics despite the fact that a homogeneous community of Muslim does not exist in Slovakia and all the migrants from the MENA region $^{10}$ actually sidestep the country? Given the fact that I apply and use a specific theoretical framework, the wider-asked questions can be reformulated as follows:

Q: Did the Slovak political actors use the migration crisis, and did they securitize this topic during the pre-election and election campaign?

$\mathrm{Q}$ : If yes, was the process of securitization successful?

Q: Was there an accompanying phenomenon anti-Muslim rhetoric in political speeches of political actors?

$\mathrm{Q}$ : What kind of narrative was used from political actors to the Islam and Muslim - a security threat or a cultural threat?

$\mathrm{Q}_{2 \mathrm{~b}}$ : Did the political parties integrate anti-Muslim agenda to their political program during the 2016 parliamentary elections?

This paper is based on a qualitative method of research as employed by Arendt Lijphart. Thus, it is an interpretative case study and its purport is to use a theoretical framework so that other cases may be tested accordingly (Lijphart 1971, 691). Moreover, applying Robert Yin separating approach, this paper represents a descriptive case study (Yin 2003). Within Robert Stake's typology of qualitative case studies, it may be perceived as an intrinsic study (Stake 1995, 3-4). In my analysis, I focus on the most powerful political actors in representative democracy - political parties. The main objects of my analysis do not include all political parties that succeeded in parliamentary election in 2016 (Table 1) but those political parties that had and still have a strong nationalist agenda, mainly the left-wing Direction-SD as a governing party with a majority rule before the general elections in 2016; the right-wing

10 Middle East and the North Africa region. 
Slovak National Party, which came back to the parliament after four years; and two political bodies in the Slovak parliament, the populist movement We Are Family and the extreme right-wing Kotleba-People's Party Our Slovakia.

The first main goal of this paper is to explain how the migration crisis was abused by Slovak political elites. The second one stresses a concern about the public and political speeches of political actors that manifest anti-Muslim and anti-Islam rhetoric instead of work of Viera Žúborová and Ingrid Borárosová (Žúborová, Borárosová 2017). In any case, to clarify, the hatred speech acts against Muslims and Islam are based on Islamophobia theory. According to the European Muslim Initiative for Social Cohesion (EMISCO), Islamophobia is "a form of intolerance and discrimination motivated with fear, mistrust and hatred Islam and its adherents. It is often manifested in combination with racism, xenophobia, anti-immigrant sentiments and religious intolerance. Manifestations of Islamophobia include hate speech, violent acts and discriminatory practices. Islamophobic rhetoric associates Muslims with terrorism and portrays them as an international and domestic threats" (EMISCO 2010). For this purpose, I analyze Islamophobic rhetoric from (a) political representatives and their political statements linked with a key word - Muslim and Islam and (b) political agenda, political manifestos, or political materials on websites of those political parties that have succeeded in election 2016.

\section{Theoretical Framework of Securitization Theory}

The end of the Cold War brought a redefinition of international environment. It changed the bipolar structure, and the meanings of key terms in international relations (IR) were also redefined. One of the concepts that was modified, and rethought, was the concept of security. Theory of securitization by COPRI ${ }^{11}$ was invented as an "update regional security complex theory which reflected the widespread feeling in the mid-1990s that the post-Cold War international system was going to be much more decentralized and regionalized in character" (Buzan et al 1998, vii). Meanwhile, Barry Buzan represented the concept with his contributions to the idea of realism. Ole Waever who coined the term of securitization was strongly influenced by poststructuralist ideas. Buzan et al in his Magnus Opus ${ }^{12}$ set out a new comprehensive security framework that

11 Copenhagen School of International Relations is associated the Conflict and Peace Research Institute (COPRI). According to Waever, "securitization" is just one of three main and innovative concepts of Copenhagen school. The others include "sector" and "regional security complexes" (McDonald 2008, 582).

12 Buzan Bary, Waever Ole, de Wilde Jaap. 1998. Security: A New Framework for Analysis. London: Lynne Rienner Publishers. 
reflects the post-Cold War debates between "wide" and "narrow" approaches to the security research.

In their new theoretical security framework, they respect the traditional narrow point of view to the security, but with other IR theorists (Brown 1989, Nye 1989, Haftendorn 1991) they have seen new security threats that have an unmilitary nature. They respect the usual five levels of IR analyses, ${ }^{13}$ but they fundamentally extend the sector agenda; it means that the places where potential threats can be detected are not just defined in the military and political sector. Buzan et al added a new research area where potential threats go on: concretely in the societal sector, environmental sector, and economic sector. ${ }^{14}$ In all these sectors, securitization can take place. What does it mean when authors speak about securitization? For Buzan et al, it represents a concept of security evoking "the moves that takes politics beyond the established rules of the game and frames the issue either as a special kind of politics or above politics" (Buzan et al 1998, 23). From this point of view, we can derive the term of securitization. For Buzan et al, securitization is a "more extremist version of politicization." In IR, environment and security theories can be topics and issues ranging from nonpoliticized through politicized to the securitized in a straight line. The securitized issues are presented as existential threats "requiring emergency measures justifying actions outside the normal bounds of political procedure presents" (Ibid, 24).

non-politicized politicized securitized

issue with no public debate issue is part of public policy issue = existential threat

Source: author based on Buzan et al. 1998

Buzan et al claim that "exact definitions and criteria of securitization are constituted by the intersubjective establishment of an existential threat with a saliency sufficient to have substantial political effects" (Ibid 25). When issues are defined as an existential threat, they become a security issue and

13 International systems - largest conglomerates of interacting or independent units; International subsystems - Asian Nations (ASEAN), Organization of African Unity (OAU); Units - various subgroups, organizations, firms, (e.g. state, nations, transnational firms); Subunits - organized groups that are able to affect the Units (e.g. lobbies, bureaucracies); Individuals - the bottom lines of social analysis (Buzan, Waever, De Wilde 1998, 5-6).

14 For more detailed analyses of the Individual sectors, see Buzan et al (1998): Military sector (p. 4971), Environmental sector (p. 71-95), Economic sector (p. 95-119), Societal sector (p. 119-141), and Political sector (p. 141-163). 
it is justifiable to use exceptional political or military measures to deal with them. How do we know that this issue is an existential threat? Waever and Buzan appeal to the textual/discourse analysis; the securitization theory is tied and connected with a linguistic theory (Waever 1995, Buzan et al 1998, 37). We can use a parallel: linguistic theory à speech act; securitization theory à securitization speech act. Chosen issues are security problems when elites (most often but not ever) declare it to be.

Buzan et al warn that the "discourse presenting something as an existential threat to a referent object does not by itself create the securitization - this is just a securitizing move; [...] the issue is securitized only if and when audience accepts it such.” Three elements are necessary for a successful securitization process: existential threats, emergency actions, and effects on interunit relations by breaking the rules (Buzan et al 1998, 25-26). Analytical processes within the speech acts approach bring the three main actors within the securitization theory: 1 : referent objects - things that are seen to be existentially threatened and have a legitimate claim to survival; 2 : securitizing actors - actors who securitize issues and declare that something - a referent object - is existentially threatened; and 3: functional actors - actors who affect the dynamics of sector; actors who significantly influence decisions in the field of security (Ibid, 36). I turn to my attention to the societal sector that is the reference framework for the migration issues. How do the Copenhagen theorists define the societal sector? What is the main agenda? Who are security actors and referent objects? What is the logic of threats and vulnerabilities in the societal sector?

The societal sector and societal security are close to the concept of national security and the political sector, but it is not the same case for Buzan et al. Whereas the political sector is based on the concept of national security and researchers are focusing on the institutionalized actor - a state, in this case, researchers analyze a society; then, "organizing the concept in the societal sector is identity" (Buzan et al 1998, 121-122). Why is not the core element in the societal sector referring to a nation as in the political sector? For Buzan et al, the societal security is about large, self-sustaining identity groups (in Europe, mainly national groups), but in other regions, religious or racial groups have more relevance. Therefore, the term identity security is also possibly used. After that, the referent objects in the societal sector "are whatever larger groups carrying the loyalties and devotion of subjects in a form and to a degree that can create a socially powerful argument that this "we" is threatened; this "we" has to be threatened as to its identity" (Ibid, 123). In the 
societal sector, three main security threats were defined. Except migration, ${ }^{15}$ there are also horizontal and vertical competitions. ${ }^{16}$ As mentioned before, the societal security is connected to the nations and ethnics in Europe. The dynamics of threats and vulnerabilities is therefore affected by a constellation of the multilevel European identity.

\section{Questionable Slovak Identity}

In relation to the earlier sketch of the theory of securitization framework, I tried to define the particular components of this theoretical framework within the Slovak case. The migration crisis is a threat that Buzan et al included in the societal sector. The essential terms within are the identity and identity security. What does Slovak nation and Slovak identity mean?

The Preamble of the Slovak Constitution reads: "We, the Slovak nation bearing in mind the political and cultural heritage of our predecessors (...) mindful of the spiritual bequest of Cyril and Methodius and the historical legacy of Great Moravia (...) together with members of national minorities and ethnic groups living on the territory of the Slovak Republic" (Preamble Constitution of the Slovak Republic 1992). The Slovak Constitution refers to the very old history of the $9^{\text {th }}$ and $10^{\text {th }}$ centuries and two main elements of modern nations - territory and language. Except for the Nazi puppet war state of 1939-1945 led by the Catholic priest Jozef Tiso, the Slovak territory and Slovaks were part of multi-ethnic empires (The Kingdom of Hungary, Habsburg empire, Austrian-Hungarian Monarchy) or a multi-ethnic state (The First Czechoslovak Republic), and therefore, the modern Slovak Republic as established in 1993 is a very young state in which the old habits from the long-time living under the communist totalitarian ideology are preserved. Moreover, one of the main factors to determine the Slovak identity is also its geographical position between Eastern and Western Europe and its historical experience with the West being still seen as a traitor due to the Vienna arbitrage in 1938 and Slovak national revival.

The lack of Western European feelings is seen in a vast number of opinion polls published in Munich Security Report 2018 (MSR 2018). Considering the first question dealing with the geopolitical orientation, only $21 \%$ choose that Slovakia is a part of the Western EU, 9\% voted for the Eastern EU,

\footnotetext{
15 Migration - The $\mathrm{X}$ people are being overrun by the $\mathrm{Y}$ people.

16 Horizontal - in practical case - the Quebecois fear of Anglophone Canada - more generally, the Canadian fear of Americanization; Vertical - people stop seeing themselves as an X because there is either an integrating project (e.g. Yugoslavia, EU) or a secessionist project (e.g. Quebec, Catalonia) that pulls them toward either narrower or wider identities (Buzan et al 1998, 121).
} 
$28 \%$ did not know how to respond, and the majority of $42 \%$ responded that the geopolitical orientation should be just between the West (EU) and East (Russia). Absolutely the lowest support of former post-communist countries has been shown within the support of NATO. Only 38\% of respondents have seen the NATO in a positive way, and $43 \%$ voted in favor of staying in the NATO structure (MSR 2018).

It is not surprising that the Prime Minister Robert Fico and Slovakia stand with other states and rejected the EU quota mechanism for a migrant redistribution (Reuters 2015). Slovakia has accepted ca. 800 migrants due to the mechanism, but Fico argued that Slovakia has no power to keep migrants in if they wish to move to richer countries of the EU, especially Germany and France. In fact, the Slovak people are very closed-minded, and they do not accept new suggestions easily. Almost all political parties have joined this governmental position through the EU quotas. Rejecting the EU policies and solutions for the EU refugee crisis also characterized the feelings within the Slovak society. Slovak political parties perceive the refugee crisis as a parallel clash of civilizations. Between the second part of 2015 and March 2016, they constantly and gradually spoke about the matter in their campaigns and used the anti-Muslimism and Islamophobia approach. I reflect how this rhetoric and speech affected the societal sector and feelings of Slovak society.

Since 2001/2002, securitization has been a frequent topic in the research area, including the migration issues (Huysmans 2002, Burbeau 2011, Ceyhan, Tsoukala 2002). Stefano Guzzini noted that the theory of securitization provided a next step for the ongoing discussion on how to better understand security (Guzzini 2011, 330). This conceptual framework was applied in many varieties: minority rights research (Roe 2014), construction of transnational crime (Emmers 2012), and state foreign policy behavior (Abrahamsen 2005). Nevertheless, that securitization theory is valued and expanded into many research areas but there is also a space for widely critical points. Matt Macdonald has three critical notes to securitization: a, the form of act constructing security is defined narrowly with a focus on the speech of dominant actors (usually political leaders); $b$, the context of the act is defined narrowly, with a focus on the moment of intervention only; and c, the nature of the act is defined solely in terms of security threat designation (McDonald 2008, 564).

The central position of speech act in securitization is just one way in which to move step by step in the securitization process. There are also visual representations affecting the securitization process, e.g. 9/11 and Iraq war (Williams 2003, Möller 2007). Another critique or alternative point of view 
for securitization may be represented by Didier Bigo from Paris School. For Parisian scholars, "security is constructed and applied to different issues and areas through a range of often routinized practices rather than only through specific speech acts that enable emergency measures" (Bigo 2002, 65). Thierry Balzacq adds that "the assumption of a speech at approach ultimately reduces security to a conventional procedure" (Balzacq 2005, 172, Balzacq et al 2016). Balzacq notes that "the critical question for securitization scholars is not whether discourse does things but instead under what conditions the social content and meaning of security produces threats (...) effective securitization is based on who does what and in what context" (Balzacq 2010, 64-66).

\section{Findings}

In the following part of my text, I focus on an accompanying phenomenon of securitization of migration crisis - Islamophobic speech. I focus on the political discourse. It is a necessary condition, but in comparison with Androvičová or Žúborová and Borárosovás contributions, I reflect the approach aiming particularly at political parties that presented the migration crisis as a security dilemma - an existential threat for the Slovak society and Slovak identity. Slovak political parties perceive the refugee crisis as a parallel clash of civilizations. Between the second part of 2015 and March 2016, they constantly and gradually spoke about the matter in their campaigns and used the anti-Muslimism and Islamophobia approach. I reflect how this rhetoric and speech affected the societal sector and feelings of Slovak society.

\section{Direction-SD (Smer-SD)}

The ruling party holding the majority in the Slovak parliament was the main actor in the securitization of migration crisis in the Slovak Republic. PM Robert Fico and Minister of Interior Robert Kalinák were the most quoted politicians from Direction-SD, Fico was absolutely the most quoted one every single month in the period between May 2015 and March 2016 (Žúborová, Borárosová 2017, 14). Not only that the PM and his government set up a negative position to the EU quota mechanism, but in his rhetoric, he openly presented himself as both anti-Muslim and anti-Islam. During the preelection time and election campaign, Direction-SD spread a moral panic in the Slovak society and the speech act increased fear of Muslims and Islam. The core elements of discourse from this party were projected in imagines stating that Muslims and Islam are incompatible with our Western value order and if the Muslims came, they would destroy our western world. In January 2015, before the refugee crisis truly began, PM Fico said in the Slovak 
broadcast, "Since the Catholic church is dominant in Slovakia, and the second most dominant one is the evangelical church, we will not tolerate three or four hundred thousand of Muslim who are coming. They will start building mosques and they will change the character of this state" (SITA 2015).

Moreover, Direction-SD party connected all Muslims with terrorism, and used this rhetoric very frequently especially following the terrorist attacks in Western Europe (Paris, Cologne). After the Paris attack, PM Fico cmailed that" (...) the rights of migrants are not important so much; the rights to protect Slovak inhabitants are the most important" and also that "the Slovak security forces are monitoring every Muslims living in the Slovak Republic" (Kysel' 2015). During the New Year Eve of 2016, riots took place in certain German cities. PM Fico argued that "there is only way to minimize the risks as we have seen in Paris and Germany. We have to prevent and create a comprehensive Muslim community in Slovakia, (...) multiculturalism in Europe has failed and it is not possible to integrate Muslims to the majority, [...] they have a different way of life, different reasoning and religion as well as cultural background." After this rhetoric, PM Fico and his party faced a huge criticism from the Slovak Muslim community and the EU institutions (Tharoor 2016, Kern 2015). Fico publicly deprived the myth that "Slovakia is a democratic and free country" as written in the statement issued by the Slovak Muslim Community (ISLAMONLINE.sk 2015). Paradoxically, before the election held in March 2016, Direction-SD did not transform migration issues to their political agenda.

The importance of migration issues concurred with the need of newly approved law against terrorism; after that, Direction-SD created a coalition government. This anti-terrorism package (Protiteoristický balíček) as usually called this act was approved in a fast-track legislative procedure (The Slovak Spectator 2015). This situation characterized one of the main characteristics of securitization based on such an extraordinary governmental approach in extraordinary situations with extraordinary measures.

\section{Slovak National Party (Slovenská národná strana)}

The Slovak National Party (SNP) established in 1990 is a successor of the Slovak National Party that had existed between 1871 and 1938 and was the first political party of Slovaks. The SNP is a clear proponent of typical nationalist parties in Europe. The ideology of this party is based on the ethnos declaring that the Slovak Republic is a state of Slovaks. What is important for this subject is the fact that the SNP did not have any MPs in the Slovak 
Parliament and in the migration discourse; they featured and created a nonparliament party.

For the SNP, Islam is not just a religion but also a political ideology and a specific system of law. The chairman of SNP, Andrej Danko, argued that "the Koran contains a lot of madness" and "WE have to do everything for Catholic Europe to remain the same Catholic Europe." The speech act of SNP leader Andrej Danko was contradictory. On one hand, in September 2016, Danko did not happen to view Slovakia as a "xenophobic and racist state" in Europe, and on the other, in a press conference in January 2015, he introduced three main pillars against the "Islamization of Europe." First, the SNP declared that as a parliamentary party, it will assert "a ban for wearing burqa." Chairman Danko admitted that the SNP was inspired by Switzerland or Belgium. Second, the SNP never accepted building a mosque and minaret in the Slovak Republic. "There is no place for minarets and mosques in Bratislava, [...] Slovakia is a state without a mosque and it must remain unchanged" as said by A. Danko. Third, the SNP proposed to increase the numbers of religious group registration from 20,000 to 50,000 (ISLAMONLINE.sk 2015a, Lenč, Zaviš 2017, 568-569).

In the pre-election period and election campaign, SNP positioned Islam against the Catholic Church. The SNP agreed with the Direction-SD and rejected the EU quota mechanism. The SNP articulated a package of requests called "The Memorandum of Poprad" (Popradské memorandum) with a main headline that stated: "Be Partners, not Slaves" (Byt partnermi, nie otrokmi). One of the main points of this memorandum was calling on the EU to "stop any implementation of multiculturalism ideology [...] which dramatically suppresses European values of Christianity" (SNS 2013). In contrast to the Direction-SD for speech act, for the SNP, it was not typical to identify Muslims with terrorism threats. For the SNP, the key accents were anti-Muslim and anti-Islam speeches evoking so-called cultural wars.

\section{We Are Family-Boris Kollár (Sme Rodina-Boris Kollár)}

Veni Vidi Vici is the best paraphrase, as well as the headline of one of the Slovak newspapers, which evaluated the success of the political movement We Are Family associated with the Slovak billionaire Boris Kollár (Hospodárske noviny 2016). This center-right movement had two main pillars in its political agenda in pre-election period: fighting the domestic political elites and spreading a fear of the migration crisis. Officially, it was a political movement established and registered at the Ministry of Interior in November 2015; yet in March 2016, it won 11 MP seats and entered the parliament. 
The We Are Family Chairman Kollár manifested his views on migration strictly on the very popular media - Facebook, YouTube, and Instagram. He brought a new phenomenon that I operationalized as a selfie video post. In monolog speeches, Kollár addressed the Slovaks, their feelings and opinions especially with emotional speeches against the Muslims, Islam, EU, etc., while doing so in a very friendly company and informal dress code. His videos were very popular and took a quick viral character.

According to the political program of We Are Family, migration is "one of the security threats" (Program Sme Rodina 2016). We Are Family defined the migrants as people with completely different civilization habits, as people who do not want to adapt our lifestyle and our value system. The movement rejected the EU mandatory mechanism of quotas and warned that "The Slovak police and armed forces must be prepared to build a fence on the borders against migrants" (Ibid 2016). The chairman considers migration to be a "controlled process of Muslim invasion into Europe that can lead to riots and civil wars" (Vaniher 2015). He noticed that the EU and its approach to the migration crisis is a sheer "euro-idiocy," and he labelled the EU bureaucracy as "euro-rubbish." Moreover, after the migration riots in Germany, Kollár recommended Germans to remove the "witch-chancellor," Angela Merkel. In his speeches, Kollár's movement or better say Kollár himself incited hatred and used a very vulgar language and slang. Many people considered his opinion to be the vox populi part of the Slovak population.

\section{Kotleba-People's Party Our Slovakia (Kotleba-L’udová strana naše Slovensko)}

"This is a moment of a great shame for Slovakia, (...) it is not like the French National Front, which is far-right. These are the Nazis" said Tom Nicholson, a British-Canadian journalist working for the daily SME who has lived in the country for 23 years (Cameron 2016). Kotleba-Our Slovakia shocked Slovakia and the rest of the world in terms of the latest results in the Slovak general election. They exceed the 5\% threshold, and with $8 \%$, the party won 14 seats. This political party represents the most-extreme right political force. Its political agenda follows the Slovak Nazis puppet state from 1939 to 1945 led by the catholic priest Jozef Tiso. It approved and manifested support toward the politics of this regime, which is linked with anti-Semitism against the Jewish and Romani communities. Many of these ideas were incorporated into the current speeches, keeping the party more flexible but still xenophobic and racist. 
As a then non-parliament party, it used a very extreme anti-Muslim and antiIslam rhetoric. In the rhetoric and writing speeches, the party extremely spreads fear of Muslims and Islam. It keeps using the "We" and "They" distinction very often. In the party newspaper called "Our Slovakia" (Naše Slovensko), exponents of Kotleba's party spoke about "the hordes of Muslim immigrants who are already taking over us with a support of Fico's government" (Naše Slovensko 2016). Some passages in the program are influenced by the neoromantic visions of the nation and include references to the God - "we will not betray our nation and God." Kotleba-Our Slovakia attacked the Slovak views of migrants through false statements - "while our children have to take mortgages and pay for a medical insurance, they have everything (housing, healthcare, food) for free, [...] each one of them costs us monthly 1,500 euros" (Ibid 2016).

Despite the fact that the Kotleba-Our Slovakia Party was not given much space in the mainstream media, the party used alternative media ${ }^{17}$ as well as support of Catholic priests (Folentová 2016). The Slovak Catholic Church and some Catholic priests have openly supported the Kotleba-Our Slovakia Party, and this fact could have affected some voters to shift from a traditional conservative party such as the Christian-Democratic Movement to a more radical party despite the fact that its agenda included Islamophobia elements.

\section{Conclusion}

It is indisputable that the migration crisis had been one of the key elements of the latest general election held in the Slovak Republic. This topic represented one of the core elements of political and societal discourse. The Slovak political elites abused this topic and securitized the migration issues despite the fact that the Slovak Republic has been hit by the refugee crisis. If we add variables to the securitization scheme in the Slovak case, it can be marked as follows:

Referent objects - the Slovaks, Slovak nation, Christianity values, and Western world order and values

Securitizing actors - Government of Slovak Republic, political parties and movements, bureaucracy, Slovak Catholic Church, and alternative media environment

Functional actors - Slovak NGO's sector and Slovak media

This securitization process succeeded in illustrating that the three nationalistic and extreme oriented political parties entered the parliament while having a migration crisis as a central component of electoral campaigns and they used

17 E.g. Free Broadcaster (Slobodný vysielač) and Info War (Infovojna). 
an extremely anti-Muslim and anti-Islam rhetoric. After the analysis, we can see some similarities in the approaches of these parties. All parties spread fear of the migration crisis, and in the speech act, they spoke about existential threats, and the Slovak society accepted this rhetoric. For all analyzed parties, there are three common characteristics of the speech acts as used during securitizing of migration in Slovak:

- Muslims will increase crime and terrorism;

- Clash of civilization (Western Value System vs. Islam Values Order) with incompatible value systems;

- Islam is a spoiled religion, and it presents a threat to Christianity.

Regarding research questions sketched out in the introduction, it is possible to make the following responses to $Q 1, Q$. The political actors securitized the migration issue in the election campaign 2016, and the securitization process has been successful. Moreover, one of the opinion polls for the Slovak Academy of Science (Slovenská akadémia vied, SAV) held in September-October 2016 supports this observation. Half a year after the general elections, $47.7 \%$ of Slovak population was "very afraid or worried" of refugees; in addition, more than $71 \%$ people did not want to help any refugees or only helped in necessary cases. The most frequent answers to the question "Why are you scared of refugees?" was associated with a higher level of crime (36.6\%), refusal to adapt to our lifestyle $(30.6 \%)$, Islamic terrorism $(28.8 \%)$, and change in culture and society (20.4\%) (SAV 2016). The most frequent answers reflect the trends from campaigns of those parties that spread a moral panic and made up a securitized migration crisis.

With regard to $Q 2, Q_{2 a}, Q_{2 b}$, one of the accompanying phenomena during the securitization process was use of anti-Muslim and anti-Islam rhetoric. All selected political actors used in their speech acts both narratives, i.e. security threats and cultural threats. These political parties, however, differed in the extent of use of these expressions. The most extreme anti-Muslim and antiIslam rhetoric was exerted by the political party Kotleba-People's Party Our Slovakia led by Marián Kotleba. This party applied the most radical rhetoric also in its political manifest. On the other hand, the speech acts of political parties Slovak National Party and We Are Family-Boris Kollar were very similar, but compared with Kotleba's party, they did not use the anti-Muslim and anti-Islam measures in their political agenda. Paradoxically, the ruling party Direction-SD led by former PM Fico lacked the migration issues in its 
political program. Fico and the then Minister of Interior Robert Kaliňák, however, opposed the EU migration policy agenda.

To conclude, Jozef Lenč, one of the most prominent scholars of Islam at Slovakia, warns that "Society - politicians, media, and teachers - should be aware that the destruction of democracy and the rise of totalitarianism in the 1930s were caused by anti-Semitism, which manifested itself with the same accompanying phenomena as Islamophobia does today in Slovakia" (Lenč, Zaviš 2018, 575). Unfortunately, as the here scrutinized parties entered the Slovak parliament, they brought with them Islamophobia and the "migration agenda" to the parliamentary level. Thankfully and when compared to other EU countries, Islamophobia has not resulted in open physical attacks on the Slovak Muslim minority in daily life.

\section{Acknowledgements}

This paper was supported by the project IGA_FF_2018_032 of the Palacký University in Olomouc.

\section{References}

Abrahamen, Rita. 2005. "Blair's Africa: The Politics of Securitization and Fear." Alternatives 30 (1): 55-80.

Androvičová, Jarmila. 2015. "Sekuritizácia migrantov na Slovensku - analýza diskurzu." [The Securitization of Migrants in Slovak Republic - Discourse analysis.] Sociológia 47 (4): 319339.

Balzacq, Thierry. 2005. "The Three Faces of Securitization: Political Agency, Audience and Context." European Journal of International Relations 11 (2): 171-201.

Balzacq, Thierry. 2010. "Constructivism and Securitization Studies." In The Routledge Handbook of Security Studies, edited by Myriam Dunn Cavelty, Victor Mauer, 56-72. LondonNew York: Routledge.

Balzacq, Thierry et al. 2016. "Securitization revisited: theory and cases." International Relations 30 (4): 494-531.

Bigo, Didier. 2002. "Security and Immigration: Towards a Critique of Governmentality of Unease.” Alternatives 27-Special Issue: 63-92.

Brown, Neville. 1989. "Climate, Ecology and International Security.” Survival 31 (6): 519532.

Burbeau, Phillipe. 2011. The Securitization of Migration: A study of movement and order. London, New York: Routledge.

Buzan, Bary. 1991. People, States and Fear: An Agenda for International Security Studies in the Post-Cold War Era. Boulder: Lynne Rienner.

Buzan Bary, Waever Ole, de Wilde Jaap. 1998. Security: A new Framework for Analysis. London: Lynne Rienner Publishers. 
Cameron, Rob. 2016. "Marian Kotleba and the rise of Slovakia's extreme right." BBC News. Accessed March 6. https://www.bbc.com/news/world-europe-35739551

Ceyhan Ayse and Tsoukala Anastassia. 2002. "The Securitization of Migration in Western Societies: Ambivalent Discourse and Policies." Alternatives: Global, Local, Political 27 Special Issue 21-39.

EMISCO. 2010. "A Proposed Definition of Islamophobia." European Muslim Initiative for Social Cohesion. Accessed November. https://www.emisco.eu/a-proposed-definition-ofislamophobia/

Emmers, Ralf. 2003. "ASEAN and the Securitization Transnational Crime in Southeast Asia." The Pacific Review 16 (3): 419-438.

Eurostat. 2018. "Migration and migrant population statistic." Eurostat. Accessed March. http://ec.europa.eu/eurostat/statistics-explained/index.php?title=Migration_and_migrant_population_statistics\#Migration_flows:_2_million_non-EU_immigrants

Folentová, Veronika. 2016. "Niektorí kňazi otvorene podporujú Kotlebu, biskupi to nekritizujú." [Some priest support Kotleba, Bishops do not critize.] Dennik N. Accessed March 11.https://dennikn.sk/401460/biskupi-kotlebu-nekritizuju-sa-cirkev-zacne-vyjadrovatjednemu-preco-nie-druhemu-ci-tretiemu

Guzzini, Stefano. 2011. “Securitization as a causal mechanism.” Security Dialogue 42 (45):329-341.

Gyarfášová, Ol'ga, Martin, Slosiarik. 2016. Vol'by do NR SR 2016: Čo charakterizovalo voličov. [Election to The National Council 2016: What's characterize voters.] Sociologický ústav SAV.

Haftendorn, Helga. 1991. "The Security Puzzle: Theory-Building and Discipline-Building in International Security.” International Studies Quarterly 35 (1): 3-17.

Hospodárske noviny. 2016. "Prišiel, videl, zvítazil. Boris Kolár vybojoval parlament v rekordnom čase." [Veni, Vidi, Vici. Boras Kolár entered to parliament in a record time.] Hospodárske noviny. Accessed March 7. https://slovensko.hnonline.sk/593412-prisiel-videl-zvitazilboris-kollar-vybojoval-parlament-v-rekordnom-case

Huysmans, Jef. "The European Union and the Securitization of Migration." Journal of Common Market Studies 38 (5): 751-777.

IOM Slovakia. 2018. "Migration in Slovakia." International Organization of Migration Slovakia. Accessed February 16. https://www.iom.sk/en/migration/migration-in-slovakia.html

ISLAMONLINE.sk. 2015. "Stanovisko islamskej nadácie k šokujúcemu výroku premiéra SR o monitorovaní každého jedného muslima." [The statement of Slovak Islamic Foundation to the words PM Fico that every Muslim in Slovak Republic is monitoring.] ISLAMONLINE.sk Accessed November 15.http://www.islamonline.sk/2015/11/stanovisko-islamskejnadacie-na-slovensku-k-sokujucemu-vyroku-predsedu-vlady-o-monitorovani-vsetkychslovenskych-muslimov/

ISLAMONLINE.sk. 2015a. "Slovenskí muslimovia sa boja. Dopady útokov v Paríži sa prejavili aj u nás." [Slovak Muslims has a fear. The attacks in Paris have also taken place in our country.] ISLAMONLINE.sk Accessed January 25. http://www.islamonline.sk/2015/01/ takto-na-slovensku-po-parizi-utocili-na-muslimov-zakazovali-mesity-aj-prepichovaligumy/ 


\section{Journal of Nationalism, Memory \& Language Politics 12(2)}

Kern, Miroslav. 2015. "Smer má problem, začínajú sa jeho rokovania o vylúčení zo Strany európskych socialistov." [Direction-SD in a trouble. Negotiations for his suspense of the European Socialis Party.] Dennik N. Accessed September 23. https://dennikn.sk/249106/ smer-ma-problem-zacinaju-rokovania-o-jeho-vyluceni-z-pes/

Kysel, Tomáš. 2015. "Moslimov pobúrili Ficove slová. Takmer všetci teroristi boli moslimovia, odkazuje im." [Muslims offended by Fico's words. Almost all of terrorists were a Muslims he answered.] Aktuality.sk. November 16. Accessed https://www.aktuality.sk/ clanok/308295/mame-zacat-nosit-zeleny-polmesiac-moslimov-poburili-ficove-slova-o-ichkontrole/

Lenč Jozef, Zaviš Monika. 2018. “Islamophobia in Slovakia: National Report 2017.” In European Islamophobia Report 2017, edited by Enes Bayraklı \& Farid Hafez, 561-576. Istanbul: SETA

Lijphart, Arendt. 1971. "Comparative Politics and Comparative Method." The American Political Science Review 65 (3): 682-693.

McDonald, Matt. 2008. "Securitization and the Construction of Security" European Journal of International Relations 14 (4): 563-587.

Möller, Frank. 2007. "Photographic Interventions in Post 9/11 Security Policy." Security Dialogue. 38 (2): 179-196.

Ministry of Interior of Slovak Republic. 2017. "Statistical Overview of Legal and Illegal Migration in the Slovak Republic." Presidium of the Police Force Bureau of Border and Alien Police. Accessed 2017 http://www.minv.sk/swift_data/source/policia/hranicna_a_cudzinecka_policia/rocenky/rok_2017/2017-rocenka-UHCP-EN.pdf

Munich Security Report. 2018. “To the Brink and Back?” Munich Security Conference. Accessed January 2018. https://www.securityconference.de/en/discussion/munich-securityreport/munich-security-report-2018/

Naše Slovensko. 2016. "Naše Slovensko: Noviny politickej strany Mariána Kotlebu.” [Our Slovakia: The newspaper of Marian Kotleba's political party] Accessed February 2016. http://www.naseslovensko.net/wp-content/uploads/2016/02/nase-slovensko-februar-2016. pdf

Nye, Joseph S. Jr. 1989. “The Contribution of Strategic Studies: Future Challenges. "Adelphi Paper No. 235 London: International Institute for Strategic Studies.

Reuters. 2015. "Slovakia files lawsuit against EU quotas to redistribute migrants." Reuters. Accessed December 2. https://www.reuters.com/article/us-europe-migrants-slovakia/slovakia-files-lawsuit-against-eu-quotas-to-redistribute-migrants-idUSKBN0TL11K20151202

Roe, Paul. 2004. "Securitization and Minority Rights: Conditions of Desecuritization." Security Dialogue 38 (2): 179-196.

Rybář Marek, Spáč Peter. 2017. "The March 2016 parliamentary elections in Slovakia: A political earthquake." Electoral Studies 45: 153-156.

SAV. 2016. "Utečenecká kríza a Slovensko.” [Refugee Crisis and Slovak Republic.] Sociologický ústav SAV. December 22. Accessed http://www.sav.sk/index.php?doc=servicesnews\&source_no=20\&news_no $=6671$ 
SITA. 2015. "Fico: Tisícky moslimov by sme tolerovali len tažko." [Thousands of Muslims with mosque is hard to tolerate.] SITA. Accessed January 25. https://www.webnoviny.sk/ fico-tisicky-moslimov-s-mesitami-by-sme-tolerovali-tazko/

Sme Rodina. 2016. "Program Sme Rodina - Boris Kolár." [Program We are Family-Boris Kolár]. Sme Rodina. https://hnutie-smerodina.sk/Program-Hnutia-Sme-Rodina.pdf

SNS. 2013. "Byt' partnermi, nie otrokmi." [Be partners, not slaves.] SNS. Accessed June 29. http://www.popradskememorandum.sk

Stake, Robert E. 1995. The Art of Case Study Research. London: Sage.

Tharoor, Ishaan. 2016. "Eastern European leaders double down on anti-migrant, anti-Muslim rhetoric." The Washington Post. Accessed January 9. https://www.washingtonpost.com/ news/worldviews/wp/2016/01/09/eastern-european-leaders-double-down-on-anti-migrantanti-muslim-rhetoric/?noredirect=on\&utm_term $=.9 \mathrm{ddac} 77 \mathrm{~d} 7 \mathrm{eee}$

The Slovak Spectator. 2015. "Cabinet passed special anti-terrorism legislation." The Slovak Spectator. Accessed November 30. https://spectator.sme.sk/c/20065078/cabinet-passedspecial-anti-terrorism-legislation-parliament-to-okay-it.html

Ústava Slovenskej Republiky [Constitution of the Slovak republic]. 1992. Accessed September 1. https://www.nrsr.sk/web/Static/sk-SK/NRSR/Doc/zd_ustava_20170907.pdf

Vaniher, L'udovít. 2015. "Kollár ide do politiky, pasoval sa za ochrancu rodiny a odporcu migrácie." [Kollár goes to the politics, he is seeing itself like a protector of families and resistant of migration.] Pravda. Accessed November 11. https://spravy.pravda.sk/parlamentnevolby-2016/clanok/373591-kollar/

Világi, Aneta. 2016. "Prvovoliči v zrkadle volieb 2016: (dis)kontinuita v trendoch voličského správania mladých ludí?" [The Firstvoters in Parliamentary Election 2016: (dis)continuity in trends of voting behavior of young people?] Prognostické práce 8 (2).

Waever, Ole. 1995. “Securitization and Desecuritization.” In On Security, edited by Ronnie D. Lipschutz. New York: Columbia University Press.

Williams, Michael C. 2003. "Word, Images, Enemies: Securitization and International Politics.” International Studies Quarterly 47 (4): 511-532.

Yin, Robert K. 2014. Case Study Research: Design and Methods. London: Sage.

Žúborová, Viera and Borárosová Ingrid. 2017. "Migration Discourse in Slovak Politics. Context and Content of Migration in Political Discourse: European Values versus Campaign Rhetoric." Journal of Nationalism, Memory \& Language Politics 11 (1): 1-19. 